\title{
Thrombotic Thrombocytopenic Purpura in a Patient with Klinefelter Syndrome
}

\author{
sinan Demircioğlu (10), Seda Yılmaz (1D, Özlen Bektaş (1), Özcan Çeneli (10
}

Thrombotic thrombocytopenic purpura (TTP) is a rare disease associated with microangiopathic hemolytic anemia, thrombocytopenia, fever, neurological disorders, and renal insufficiency pentad. It is a fatal hematologic emergency if left untreated. If plasma exchange is feasible, treatment is easy and comfortable. It should be kept in mind that such as in our patient may be acquired at all congenital illnesses.

Keywords: Klinefelter syndrome, thrombotic thrombocytopenic purpura, plasma exchange

ORCID IDs of all authors: S.D. 0000-0003-12775105; S.Y. 0000-0002-7222-499X; Ö.B. 0000-00022670-022X; 0̈.Ç. 0000-0003-2541-1335.

This study was presented at $2^{\text {nd }}$ Selim Hematology Symposium, 24-26 February 2018, Antalya, Turkey.

Department of Hematology, Necmettin Erbakan University Meram School of Medicine, Konya, Turkey

Address for Correspondence:

Sinan Demircioğlu

E-mail: sinandemircioglumd@gmail.com

Received: 17.07.2017

Accepted: 29.11.2017

(C) Copyright 2018 by Available online at istanbulmedicaljournal.org

\section{Introduction}

Klinefelter syndrome is the most common congenital anomaly, which causes primary hypogonadism. This syndrome affects 1 in 1,000 newborn males (1). The most common genotype is $46, X X Y$. However, more and less $X$ chromosomes have also been reported, leading to karyotypes such as 48,XXXY and 46,XY/46,XXY mosaic (2). A decrease in the testosterone level and an increase in the FSH-LH levels lead to testis atrophy, infertility, and decreased virilization (3). In later life stages, it may cause morbidity unrelated to testosterone deficiency (4), such as lung diseases (chronic bronchitis, bronchiectasis, and emphysema), cancers (germ cell tumors, breast cancer, and non-Hodgkin's lymphoma), varicose veins leading to leg ulcers, systemic lupus erythematosus (SLE), and diabetes mellitus due to extra X chromosome (5-9). Herein, we report the development of acquired thrombotic thrombocytopenic purpura (TTP) in a patient with Klinefelter syndrome.

\section{Case Presentation}

A 36-year-old male with Klinefelter syndrome was admitted to the emergency service with a week-long history of headache, which increased in severity and changes in consciousness. The patient was assessed in the emergency department; he was unconscious and nonresponsive to the painful stimulus. His blood pressure was $90 / 60 \mathrm{mmHg}$, pulse rate was $116 / \mathrm{min}$, and fever was $36.7^{\circ} \mathrm{C}$. In the tests performed, his WBC was $10900 / \mu \mathrm{L}$ (range, 4000-10000), hemoglobin was $6.2 \mathrm{~g} / \mathrm{dL}$ (range, 13-17), platelet count was $7000 / \mu \mathrm{L}$ (range, 150000-450000), reticulocyte percentage was $17.2 \%$ (range, $0.5 \%-2 \%$ ), creatinine was $1.39 \mathrm{mg} / \mathrm{dL}$ (range, 0.7-1.2), LDH was $1749 \mathrm{U} / \mathrm{L}$ (range, 125-220), total bilirubin was $1.99 \mathrm{mg} / \mathrm{dL}$ (range, 0.2-1.2), indirect bilirubin was $1.33 \mathrm{mg} / \mathrm{dL}$ (range, 0.1-0.7), SGPT was $33 \mathrm{U} / \mathrm{L}$ (range, 0-55), and SGOT was $68 \mathrm{U} / \mathrm{L}$ (range, 5-34). Direct and indirect Coombs tests were negative, and haptoglobulin was $<9 \mathrm{mg} /$ $\mathrm{dL}$ (range, 40-240), B12 was $291 \mathrm{pg} / \mathrm{mL}$ (range, 195-961), and folic acid was $3.51 \mathrm{ng} / \mathrm{mL}$ (range, 3.1-19.9). Antinuclear antibody was detected as negative. In a peripheral smear spread, extensive schistocytes and thrombocytopenia were observed in each region (Figure-1).

The case report was presented after obtaining informed consent from the patient.

Considering thrombotic thrombocytopenic purpura (TTP), a blood sample for ADAMTS13 was taken, and methylprednisolone $1 \mathrm{mg} / \mathrm{kg} /$ day was initiated; in addition, 1 plasma volume of plasma exchange was performed. After the first plasmapheresis, the patient gained consciousness, $\mathrm{LDH}$ dropped to $377 \mathrm{U} / \mathrm{L}$, and platelet count increased to $47000 / \mu \mathrm{L}$. Plasma exchange was continued. After the third plasmapheresis, the platelet count was $164000 / \mu \mathrm{L}$. Treatment was supplemented with acetylsalicylic acid $100 \mathrm{mg} /$ day. ADAMTS13 activity was $<0.2 \%$ (range, 40\%-1330\%), ADAMTS13 antigen was $0.06 \mu \mathrm{g} / \mathrm{mL}$ (range, 0.6-1.6), and ADAMTS13 inhibitor level was $60.90 \mathrm{U} / \mathrm{mL}(<12)$. The patient was diagnosed as having acquired TTP. Plasma exchange 


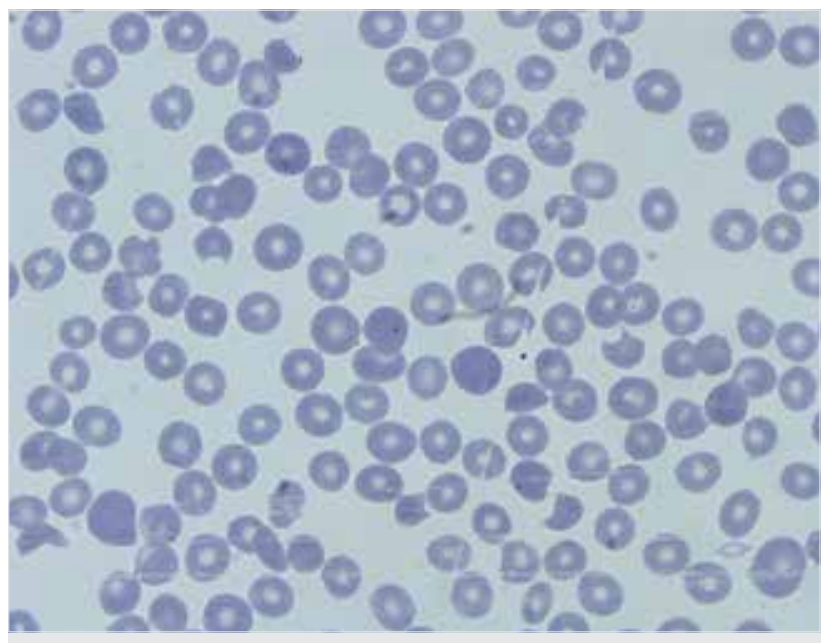

Figure 1. Common schistocytes and thrombocytopenia

was performed 11 times in total, and methylprednisolone was decreased and then cut off within 3 months. The patient is still in remission. The patient's consent was obtained.

\section{Discussion}

Thrombotic thrombocytopenic purpura is a thrombotic microangiopathy caused by severely reduced activity of ADAMTS13, which disrupts the von Willebrand factor (10). Thrombocytopenia is characterized by microangiopathic hemolytic anemia and thrombus occlusion of small vessels causing organ damage. TTP is a medical emergency that is almost always fatal if appropriate treatment is not initiated immediately (11). Survival rates above $90 \%$ are possible with appropriate treatment. The incidence is approximately 3 in 1,000,000 a year. More than 95\% of TTP cases are acquired cases with inhibitors against ADAMTS13, whereas hereditary cases characterized by the absence of ADAMTS13 constitute $<5 \%$ of all TTP cases (12). With plasma exchange performed during the treatment, the donor-derived ADAMTS13 is provided to the patient and the autoantibodies against ADAMTS13 are removed. As with our patient, the responses after plasma exchange are usually satisfactory, even with a few sessions (12). Acquired TTP may also develop in patients with other autoimmune disorders, such as SLE. It is believed that this relationship may be due to a combination of similar demographics and/or similar pathophysiology.

We did not find any association between Klinefelter syndrome and TTP in the literature. However, there is evidence that the incidence of SLE is increased among patients with Klinefelter syndrome. Scofield et al. showed that SLE is 14 times more common among patients with Klinefelter syndrome with 46,XXY karyotype than $46, X Y$ males with normal karyotypes. It is argued that this increase may be due to the extra $X$ chromosome because autoimmune diseases are more frequently seen among women (9). The increased frequency of acquired TTP among patients with SLE and the more frequent occurrence of SLE among patients with Klinefelter syndrome compared with normal men suggest that acquired TTP among patients with Klinefelter syndrome is associated with autoimmunity. However, due to the lack of such studies or case presentations in the literature, there is insufficient data in this regard. In our case, there was no clinical or laboratory finding supporting this hypothesis that suggested the presence of an autoimmune disease, such as SLE.
Randomized controlled studies are required to establish this relationship. To the best of our knowledge, this is the first reported case in the literature with Klinefelter syndrome wherein the patient developed acquired TTP.

\section{Conclusion}

TTP is rarely congenital and often acquired. Congenital diseases or other comorbid conditions of patients may delay diagnosis. If it is untreated, it is fatal; therefore, all patients with microangiopathic hemolytic anemia and thrombocytopenia should be approached as a TTP case until proven otherwise.

Informed Consent: Informed consent was obtained from the patients who participated in this study.

Peer-review: Externally peer-reviewed.

Author Contributions: Concept - S.D, S.Y.,Ö.B .; Design - S.D.,S.Y., Ö.B.; Supervision S.D.,S.Y ., Ö.C.; Resource - S.D., Ö.B.,Ö.C.; Materials S.D.,S.Y.,; Data Collection and/or Processing S.D, ., Ö.Ç; Analysis and/or Interpretation Ö.C.., Ö.B., ; Literature Search S.D., Ö.C.., ; Writing S.D, Ö.C.., ; Critical Reviews S.D, Ö.Ç,

Conflict of Interest: The authors have no conflict of interest to declare.

Financial Disclosure: The authors declared that this study has received no financial support.

\section{References}

1. Schwartz ID, Root AW. The Klinefelter syndrome of testicular dysgenesis. Endocrinol Metab Clin North Am 1991; 20: 153-63.

2. Paulsen CA, Gordon DL, Carpenter RW, Gandy HM, Drucker WD. Klinefelter's syndrome and its variants: a hormonal and chromosomal study. Recent Prog Horm Res 1968; 24: 321-63. [CrossRef]

3. Wang C, Baker HW, Burger HG, De Kretser DM, Hudson B. Hormonal studies in Klinefelter's syndrome. Clin Endocrinol (Oxf) 1975; 4: 399411. [CrossRef]

4. Bojesen A, Juul S, Birkebaek NH, Gravholt CH. Morbidity in Klinefelter syndrome: a Danish register study based on hospital discharge diagnoses. J Clin Endocrinol Metab 2006; 91: 1254-60. [CrossRef]

5. VölkI TM, Langer T, Aigner T, Greess H, Beck JD, Rauch AM, et al. Klinefelter syndrome and mediastinal germ cell tumors. Am J Med Genet A. 2006; 140: 471-81. [CrossRef]

6. Weiss JR, Moysich KB, Swede H. Epidemiology of male breast cancer. Cancer Epidemiol Biomarkers Prev 2005; 14: 20-6.

7. Swerdlow AJ, Schoemaker MJ, Higgins CD, Wright AF, Jacobs PA, UK Clinical Cytogenetics Group. Cancer incidence and mortality in men with Klinefelter syndrome: a cohort study. J Natl Cancer Inst 2005; 97 : 1204-10. [CrossRef]

8. Campbell WA, Newton MS, Price WH. Hypostatic leg ulceration and Klinefelter's syndrome. J Ment Defic Res. 1980; 24: 115-7. [CrossRef]

9. Scofield RH, Bruner GR, Namjou B, Kimberly RP, Ramsey-Goldman $R$, Petri M, et al. Klinefelter's syndrome $(47, X X Y)$ in male systemic lupus erythematosus patients: support for the notion of a genedose effect from the X chromosome. Arthritis Rheum 2008; 58 : 2511-7. [CrossRef]

10. George JN, Nester CM. Syndromes of thrombotic microangiopathy. N Engl J Med 2014; 371: 654-66. [CrossRef]

11. Rock GA, Shumak KH, Buskard NA, Blanchette VS, Kelton JG, Nair $\mathrm{RC}$, et al. Comparison of plasma exchange with plasma infusion in the treatment of thrombotic thrombocytopenic purpura. Canadian Apheresis Study Group. N Engl J Med 199; 325: 393-7. 
12. Moatti-Cohen M, Garrec C, Wolf M, Boisseau P, Galicier L, Azoulay E, et al. Unexpected frequency of Upshaw-Schulman syndrome in pregnancy-onset thrombotic thrombocytopenic purpura. Blood 2012; 119: 5888-97. [CrossRef]
Cite this article as: Demircioğlu S, Yılmaz S, Bektaș Ö, Çeneli Ö. Thrombotic Thrombocytopenic Purpura in a Patient with Klinefelter Syndrome. İstanbul Med J 2018; 19: 170-2 